rily present 2 Moore, Int. Law Dig., p. 292; United States $v$. Rodgers, 150 U. S. 249, 260; Wildenhus's Case, 120 U. S. 1, 12; and, as said by Chief Justice Marshall, in Murray $v$. Schooner Charming Betsy, 2 Cranch, 64, 118:

". . an act of Congress ought never to be construed to violate the law of nations if any other possible construction remains. . . ."

That the Government has full power under the Volstead Act to prevent the landing or transshipment of any such liquors or their use in our ports is not doubted, and therefore it may provide for such assurances and safeguards as it may deem necessary to those ends. Nor do I doubt the power of Congress to do all that the court now holds has been done by that Act, but such power exists not under the Eighteenth Amendment, to whose provisions the Act is confined, but by virtue of other provisions of the Constitution, which Congress here has not attempted to exercise. With great deference to the contrary conclusion of the court, due regard for the principles of international comity, which exist between friendly nations, in my opinion, forbids the construction of the Eighteenth Amendment and of the Act which the present decision advances.

JAMES Brown Scott.

\title{
STATUS OF THE INHABITANTS OF MANDATED TERRITORY
}

Precedents are gradually establishing the precise position of the mandated territories in the system of international law. Recent decisions seem to make it clear (1) that the mandated territories are not under the sovereignty of the mandatories, and (2) that the inhabitants of these territories are not nationals of the mandatories.

I

The first of these questions has arisen in connection with the claim of mandatories to enforce treason laws, to appropriate vacant lands and to apply treaties in mandated areas. During the summer of 1922 South Africa was confronted by a serious rebellion of the Bondelzwarts in its mandated territory of Southwest Africa. After suppression of the rebellion, ${ }^{1}$ one of its leaders, Jacobus Christian, was convicted of high treason and sentenced to five years' imprisonment by the local circuit court. ${ }^{2}$ Upon appeal to the Supreme Court of the Union of South Africa the indictment was sustained.

1 The methods employed gave rise to severe criticism in the Assembly (Levermore, League of Nations Year Book, 1923, Vol. 3, p. 276), and to a lengthy investigation by the Permanent Mandates Commission, as a result of which the commission drew attention to the failure of the mandatory itself to make a "complete and authoritative inquiry" (Permanent Mandates Commission, Minutes, 3rd sess., 1923, p. 291) and to the harshness of the methods of suppression and the insufficiency of the remedial measures. (Ibid., p. 294.) The commission likewise deplored the unfortunate relations which the report disclosed between the white population and a large proportion of the natives of the mandated territory. (Ibid., p. 325.)

2 Permanent Mandates Commission, Minutes, 3rd sess., 1923, p. 295.

Christian v. Rex, Supreme Court of South Africa, Cape Times, Dec. 1, 1923. 
In answering the argument that "high treason-the hoogverraad or perduello of the Roman Dutch law - can only be committed against a sovereign Power which acknowledges no superior, and the mandatory is not such a power," the court made a detailed investigation of the authority of the Union of South Africa in the mandated territory. It reached "the definite conclusion" that "the Government of Southwest Africa is not possessed of majestas in the full sense of that term; in other words, it is not a sovereign and independent state." Furthermore, though by Article 119 of the Treaty of Versailles, "Germany renounced in favor of the Principal Allied and Associated Powers all her rights and titles over her overseas possessions," she did not cede these territories to all or any one of these Powers. " "The animus essential to a legal cession was not present on either side. For the signatories must have intended that such possessions should be dealt with as provided by Part I (the League of Nations Covenant) of the treaty and they were placed at the disposal of the Principal Powers merely that the latter might take all necessary steps for their administration on a mandatory basis. - . The intention of the signatories seems to have been to place certain overseas possessions relinquished by Germany upon a basis new to international law and regulated primarily by Article 22 of the treaty."

The League of Nations, however, though sometimes referred to rhetorically as a "superstate" and "regarded in certain clauses of the treaty as possessing a distinct international persona," is in reality "an association of states which, while retaining their own sovereignty and status, have agreed with one another to pursue a certain line of conduct in international affairs as laid down in the Covenant and to cooperate in certain matters of general concern. It functions through an Assembly, a Council and a permanent Secretariat, but none of these have any compulsory power over the individual states. . . . It is not a state, it owns no territory, governs no subjects and is not endowed with the attribute of sovereignty."

Thus the court was unable to consider Southwest Africa as under the sovereignty of the mandatory, or of the Principal Allied and Associated Powers, or of the League. The powers of the various organs concerned in this "situation new to international law" could, therefore, only be discovered by reference to the terms of Article 22 of the Covenant and the mandate. These disclosed that, though the Government of Southwest Africa was limited externally by "some degree of supervisory authority" in the Council of the League, internally it was subject to no limitations except such as it had undertaken by agreement similar to treaty in accepting the mandate. Both Article 22 and the mandate recognized the mandatory of Southwest Africa as having "full power of administration and legislation" in that

\footnotetext{
- In support of this distinction, the court noticed that in the genuine cessions of territory the successor was burdened with a part of the German pre-war debt (Art. 254) and Germany was given reparations credit for public property in the territory. (Art. 256.) This was not true of the territory put under mandate. (Arts. 120, 257.)
} 
territory. Thus the Government of Southwest Africa exercising the authority of the Union of South Africa might be said to have internal sovereignty, and "majestas operating internally may by our law be sufficient to found a charge of high treason in spite of the fact that its external operation is considerably curtailed." The Union of South Africa itself as an independent signatory of the peace treaties and a member of the League of $\mathrm{Na}$ tions had an international status "clearly consistent with the possession of majestas by its government in the capacity of mandatory." Consequently "the allegation in the indictment that the accused owed allegiance to His Majesty King George the Fifth in his Government of the Union of South Africa was not open to objection." 5

A similar conclusion with regard to the mandatory's want of sovereignty was reached in an elaborate report by $M$. van Rees of the Permanent Mandates Commission on the system of state lands in B and C mandated territories. $^{6}$ The report presented at the third session of the commission examines the opinions of writers both for ${ }^{7}$ and against ${ }^{8}$ the attribution of sovereignty to the mandatories and accepts the latter view. M. van Rees does not find it necessary for his purpose to decide whether sovereignty is vested in the League, ${ }^{9}$ or in the Principal Allied and Associated Powers, ${ }^{10}$ or elsewhere. He believes, however, that the mandatory may enjoy full "legislative, administrative and judicial power" without having sovereignty of the territory. In fact the old trading companies, such as the Dutch and the British East India companies, possessed analogous powers without the attributes of sovereignty. The terms of Article 22 of the Covenant and of the mandates show "that under the mandate system the mandatory state is merely the governor of the territory which does not belong to it." Thus articles of the Treaty of Versailles by which property and possessions of the German Empire or any German state "shall pass to the government exer-

- An analogy may be noted to the power of the States of the United States to punish persons for treason against themselves though they lack sovereignty as understood by international law (Wharton, Criminal Law, sec. 1812), and of military governments to punish for "war treason" the inhabitants of occupied territory over which they have only temporary jurisdiction (U.S. Rules of Warfare, 1914, secs. 202, 203, 207; Oppenheim, International Law, 3rd ed., sec. 162).

- Permanent Mandates Commission, Minutes, 3rd sess., 1923, annex 2, pp. 216-239.

"M. R. E. Rolin, "Les systemes des mandats coloniaux," Rev. de droit int. et de lég. comp., 1920 , p. 329.

- John H. Harris, "The Challenge of the Mandates," Contemporary Review, 1921; British League of Nations Union, A plan for government by mandates in Africa, 1921; M. von Kol, "Colonial Mandates and the League of Nations," Preliminary Documents of the Twentieth Interparliamentary Union, p. 76. See also Wright, "Sovereignty of the Mandates," this JoURNAL, 17: 695, Oct. 1923.

- As argued by Schucking and Wehberg, Die Satzung des Volkerbundes, Berlin, 1921, p. 423. See also Wright, op. cit., p. 697, and M. D'Andrade, Permanent Mandates Commission, Minutes, 1st sess., 1921, pp. 41-42.

${ }^{10}$ See M. Rappard, Permanent Mandates Commission, Minutes, 2nd sess., p. 42; Wright, op. cit., pp. 697, 699. 
cising authority over such territories" (Art. 120) or "shall be transferred with the territories to the mandatory Powers in its capacity as such" (Art. 257) do not give the mandatory state a title to such property." "The territory, property, possessions and rights referred to in the two articles do not belong to the mandatory state, but have merely been placed at its disposal; it has been granted their use in order that it may carry out its duties as governor with which it has been entrusted." 12 Although the Permanent Mandates Commission deferred final decision upon the character of public land tenure in the mandated territories, it questioned the right of South Africa to appropriate the property of the Southwest African railway "in full dominium," 13 and of France to treat public lands in Togoland and the Cameroons as "private domain of the state." 14 The question, according to M. Rappard, Director of the Mandates Section of the Secretariat, would only have significance in the case of "a change of the mandatory Power." In such circumstances, if $M$. van Rees's theory were followed, "the territory as well as the attributes of the mandatory Power would pass to another Power." 15

The mandatory's want of sovereignty over mandated territory was again indicated through the disclosure by representatives of some of the mandatories that states with which they had commercial treaties refused to give the benefit of these treaties to goods from mandated territory. ${ }^{16}$ The commission, while noting that mandatories were expressly required by the $\mathrm{B}$ mandates to apply "general international conventions" applicable to territory contiguous to the mandated territory, were of the opinion "that the man-

"S Supra, note 4.

12 Permanent Mandates Commission, Minutes, 3rd sess., p. $221 . \quad$ See also pp. 21, 162, 195.

13 Ibid., pp. 107, 325.

"Ibid., p. 30.

26 I.e., the former mandatory would not have any claim to continued title to or to compensation for public property left in the territory. (Ibid., p. 30.) The A mandates expressly secure to some extent the financial rights of the mandatory in the territory in case of termination of the mandate. (Keith, Journ. of Comp. Leg., 3rd ser. 4: 80; Wright, op. cit., 17: 700.) The distinction can be illustrated by considering the Shantung articles of the Treaty of Versailles. By these articles Germany ceded to Japan political privileges, concessions, public archives and "movable and immovable property owned by the German state in the territory of Kiau Chau." Germany had acquired these rights as a result of the lease agreement with China of 1898. Had her rights in the leased territory of Shantung been analogous to the mandatory's rights in mandated territory under $M$. van Rees's theory, it would seem that she could not cede them to Japan, because upon the termination of her administration of Kiau Chau they would automatically revert to China. China in fact made this contention. (Chinese representative Koo at Washington Conference, December 3, 1921, 67th Cong., 2d sess., Sen. Doc. 126, p. 539; Quigley, "Legal Phases of the Shantung Question," Minn. Law Rev., April, 1922, p. 383.)

16 Great Britain was unable to obtain most-favored-nation treatment for goods from Tanganyika (Permanent Mandates Commission, Minutes, 3rd sess., 1923, p. 27) and South Africa was unable to obtain such treatment for goods from Southwest Africa. (Ibid., p. 110.) 
dated territory, although administered as an integral part of the mandatory (as in the case of $\mathrm{C}$ mandates), constitutes a distinct entity, from the international point of view, and that accordingly international treaties signed by the mandatory state do not apply de jure to territory under C (or B) mandates." ${ }^{17}$ The same principle would apply a fortiori to A mandated territory. In order to prevent discrimination against the mandated territories, the commission urged the mandatories and members of the League to make special agreements reciprocally extending such conventions to the mandated areas. ${ }^{18}$

\section{II}

The status of the inhabitants of mandated territories has occupied much attention in the League, with the final conclusion that such inhabitants, whether native or of European origin, do not automatically become nationals of the mandatory; that they can not be compelled to become nationals of the mandatory, though by the Treaty of Versailles (Art. 122) the mandatories of former German territory might expel or fix conditions of residence of "German subjects of European origin," and that the mandatory may provide for the individual and voluntary naturalization of any inhabitant.

The status of these persons has not been defined, though the term "administered or protected persons under mandate" has been suggested..$^{19}$ However, the terms of the Treaty of Versailles, the Covenant and the mandates, make it clear that persons under $B$ and $C$ mandates can not be drafted for military service outside the mandated territory, except for necessary defence $;{ }^{20}$ that they are entitled to freedom of conscience and religion and to protection from slave, arms and liquor trade; ${ }^{21}$ that they have a right to petition the League of Nations for redress of grievances, 22 and that they can enjoy the diplomatic protection of the mandatory while abroad. ${ }^{23}$ The Su-

17 Permanent Mandates Commission, Minutes, 3rd sess., 1923, p. 310. With this ruling, countries like the United States, which, because of non-membership in the League, are not entitled to equal treatment in the mandated areas by the terms of the Covenant and the mandates, can not be sure of such treatment through most-favored-nation clauses with the mandatory unless the latter expressly apply to the mandated areas. The United States has in fact endeavored to conclude such special agreements. See statement of Secretary of State Hughes, Foreign Affairs, Supp., Vol. 2, No. 2, Feb. 1924, p. xix.)

18 Permanent Mandates Commission, Minutes, 3rd sess., p. 310. See also pp. 90, 171, 176, 194. This recommendation has been endorsed by the Council. (League of Nations Monthly Summary, 3: 306.) For reference to the interest of the United States in equality of economic opportunity in the mandated areas see Permanent Mandates Commission, Minutes, 1st sess., 1921, p. 21; 3rd sess., 1923, p. 27.

19 Ibid., 2nd sess., pp. 20, 66, 68; League of Nations Official Journal, 4: 568.

${ }^{20}$ Permanent Mandates Commission, Minutes, 1st sess., 1921, p. 24; 3rd sess., 1923, pp. 26, 157, 196, 311, 319.

"1 Ibid., report on 2nd sess., 1922, p. 6; Minutes, 3rd sess., 1923, pp. 256-279, 309, 311.

$n$ Permanent Mandates Commission, Minutes, 2nd sess., 1922, pp. 15, 36, 76; League of Nations Official Journal, 9: 604, 606; 4: 200, 211, 298; Wright, this JourNAL, 17: 702.

2 Treaty of Versailles, Art. 127; League of Nations Official Journal, s: 594, 608; 4: 658; 
preme Court of South Africa has held that inhabitants of $\mathrm{C}$ mandated territory, at least, owe a certain allegiance to the mandatory which may render them liable for treason." Though nationality is often spoken of as "the reciprocal relation of allegiance and protection on the part of the person and the state," 25 states often extend diplomatic protection to persons not nationals, ${ }^{26}$ and persons not nationals may be prosecuted for treason. ${ }^{27}$ Thus there is no contradiction between these privileges and liabilities of the inhabitant of mandated territory and his want of mandatory nationality. ${ }^{28}$

The question of the status of inhabitants of the mandated areas arose even before the mandates were confirmed. Sir John Salmond, Solicitor General of New Zealand, gave his government an opinion on September 30, 1919 , that inhabitants of western Samoa had not acquired New Zealand nationality by the assignment of the mandate; that under New Zealand law they could not acquire it while resident in Samoa, and that under British imperial law it was doubtful whether New Zealand could provide for their naturalization. ${ }^{29}$ On September 18, 1920, General Smuts, Prime Minister of South Africa; told the German inhabitants of Southwest Africa that "in effect, the relations between the Southwest Protectorate and the Union amount to annexation in all but name"; that the mandatory provisions were designed to offer protection to the "indigenous population"; that the inhabitants of German origin who had not been expelled as they might have been under the treaty (Art. 122) could not look to Germany for protection; that they were not nationals of South Africa; that the Union was anxious to have them become citizens, but would bring no pressure to bear. ${ }^{30}$ Later General Smuts expressed the conviction that the only solution would be to make these Germans, Union Citizens by general act, giving an opportunity of individual refusal. ${ }^{31}$ In both of these instances the question had arisen

Permanent Mandates Commission, Minutes, 2nd sess., 1922, p. 19, 67; 3rd sess., 1923, p. 310.

24 Supra, note 3.

${ }^{25}$ Wilson and Tucker, International Law, 8th ed., p. 131; Hyde, International Law, 1: 610; Luria $v$. U. S., 231 U. S. 9, 1913; Tunis case, Permanent Court of International Justice, Acts and Documents, Vol. 2, p. 116.

${ }^{20}$ As to inhabitants of protectorates, see opinion of Sir John Salmond of New Zealand, May 11, 1920, Permanent Mandates Commission, Minutes, 2nd sess., p. 69. For other classes of non-nationals who have been given protection, see Borchard, Diplomatic Protection of Citizens Abroad, pp. 463-478, 568-574.

${ }^{27}$ In the United States treason laws may be applied against domiciled aliens. (Pomeroy, Constitutional Law, sec. 432.)

see resolution II, infra, note 43.

${ }^{20}$ Permanent Mandates Commission, Minutes, 2nd sess., 1922, p. 67. See also opinion of Sir John Salmond, May 11, 1920, including statement that the Samoans had the right under the peace treaty "to become incorporated in the British Empire if they so desired." The Permanent Mandates Commission put itself on record as unable to understand this. Ibid., p. 68.

so Ibid., 2nd sess., 1922, p. 92.

s Letter of July 4, 1922, to M. Rappard, ibid., 2nd sess., p. 91. 
with regard to persons of German origin who had not been repatriated, and in neither case did the mandatory evince any intention of considering that such persons had automatically become nationals of the mandatory.

During the first session of the Permanent Mandates Commission, on October 7, 1921, while the Southwest African report was under discussion, $M$. Rappard, Director of the Mandates Section of the Secretariat, drew the attention of the commission to the difference of opinion between those who held that the mandatory could impose its nationality upon inhabitants of the mandated territory and those who held that the mandatory's nationality could only be acquired by voluntary naturalization, remarking that "the former view appeared to strengthen the argument of those who maintained that a $\mathrm{C}$ mandate amounted to disguised annexation." The members of the commission expressed very diverse opinions on the subject and it was decided to draw the Council's attention to the matter. ${ }^{32}$

At its meeting on October 10,1921, the Council, in accordance with this suggestion, appointed a subcommittee of the Permanent Mandates Commission to examine the question. ${ }^{33}$ This subcommittee obtained the views of the mandatories, in most cases by personal interviews, disclosing a considerable divergence of opinion. ${ }^{34}$ M. Matsuda, of Japan, thought it "contrary to the spirit of Article 22 of the Covenant to assimilate the native inhabitants of mandated territory to the subjects of the mandatory Power. On the other hand, having in mind the interests of these peoples, they should be accorded every advantage granted to subjects of the mandatory Power." Consequently, "they occupied a new position in international law and ought to receive a new legal status." Inhabitants other than native should, however, preserve their original nationality, in his opinion. ${ }^{35}$ Representatives of New Zealand and Australia took a similar position. They regarded the natives as "British protected persons" and contemplated naturalization of the Germans, if difficulties of the kind suggested by Sir John Salmond could be avoided by British imperial legislation. ${ }^{36}$ The representative of South Africa, Sir Edgar Walton, pointed out that Southwest Africa was the only mandated territory with a large German population, and experience had proved that it was impossible to govern unless these Germans were naturalized, in which case they could participate in the government on equal terms with the resident South Africans and could also be represented in the Union parliament. South Africa, therefore, hoped to obtain British and League consent to the naturalization of these people. The subcommittee raised the question whether this procedure would not "risk destroying a distinction essential for the maintenance of the system of mandates." ${ }^{87}$ The British

* Permanent Mandates Commission, Minutes, 1st sess., 1921, p. 41.

a Ibid., 2nd sess., 1922, p. 85. Minutes of 14th session of the Council, p. 125.

"2 Report, League of Nations Official Journal, s: 589-608.

as Ibid., s: 592.

Ibid., s: 592.

"I Ibid., 3: 593, 598. 
and French representatives considered the native inhabitants of mandated territory as protected persons whose naturalization they did not contemplate. Germans had all been repatriated in the territories under their mandate. $^{38}$ The Belgian colonial ministers who were interviewed, at first developed an elaborate argument for extending Belgian nationality to the native inhabitants as a privilege necessary to assure them the protection contemplated by the treaty and the mandate. After M. Rappard had drawn their attention to the limitation this might impose upon the right of native inhabitants to petition the League and of the League to supervise their protection as required by the Covenant, the Belgians presented a written opinion similar to that given by the British and French representatives. ${ }^{89}$ At its meeting, May 12, 1922, the Council considered this report and requested the Permanent Mandates Commission to submit definite proposals on the basis of it. ${ }^{40}$

The Permanent Mandates Commission considered the question at its second session, August 1 to 11,1922 . The special situation in Southwest Africa was considered, but the commission was unable to reconcile collective naturalization with the separate status of mandatories contemplated by the Covenant." Consequently, it drafted a resolution proposing that native inhabitants be given a distinct status, that the mandatory define this status, and that the mandatory be entitled to provide by law for "the individual and purely voluntary naturalization of any inhabitants of the mandated area." 42 These resolutions were accepted with slight modifications by the Council in its meeting of April 23, 1923, as follows:43

The Council of the League of Nations,

Having considered the report of the Permanent Mandates Commission on the national status of the inhabitants of territories under B and $\mathbf{C}$ mandates.

In accordance with the principles laid down in Article 22 of the Covenant:

Resolves as follows:

(1) The status of the native inhabitants of a mandated territory is distinct from that of the nationals of the Mandatory Power and cannot be identified therewith by any process having general application.

(2) The native inhabitants of a mandated territory are not invested

"Report, League of Nations Official Journal, s: 593-595.

Ibid., s: 594, 600-607.

10 Ibid., 3: 524 .

a Permanent Mandates Commission, Minutes, 2nd sess., 1922, pp. 16-19, 86. The commission also reached the conclusion that, under general principles of international law, Germans in the mandated areas did not automatically lose their German nationality. Ibid., p. 17.

Ibid., 2nd sess., 1922, pp. 19, 65-68, 73; League of Nations Official Journal, 4: 659.

- League of Nations Official Journal, 1923, 4: 604. The distinct status which the United States accords the nationals of the Philippines was referred to as a precedent for the proposed atatus of inhabitants in the mandated territories. Ibid., 4: 569 . 
with the nationality of the Mandatory Power by reason of the protection extended to them.

(3) It is not inconsistent with (1) and (2) above that individual inhabitants of the mandated territory should voluntarily obtain naturalization from the Mandatory Power in accordance with arrangements which it is open to such Power to make, with this object under its own law.

(4) It is desirable that native inhabitants who receive the protection of the Mandatory Power should in each case be designated by some form of descriptive title which will specify their status under the mandate.

While vote on this resolution was still pending, an extended debate took place on the question of recognizing the right of South Africa to provide for collective naturalization of the persons of German origin in her mandated territory. ${ }^{44}$ The South African delegate called attention to Article 122 of the Treaty of Versailles by which a mandatory which did not repatriate German subjects of European origin might provide conditions upon which they "shall or shall not be allowed to reside, hold property, trade or exercise a profession" in the mandated area, and proposed that South Africa be authorized to confer British nationality on the Germans of Southwest Africa, with the proviso that every such inhabitant might decline, and those who did so might remain and would not be disturbed or molested in any way..$^{45}$ The Council then voted, with M. Branting of Sweden abstaining: ${ }^{46}$

The Council of the League of Nations, taking into consideration the special case presented to it and the fact that only the inhabitants of Southwest Africa alluded to in Article 122 of the Treaty of Versailles are concerned, takes note of the declaration made by the representative of South Africa and sees no objection to the proposed action.

There has been no decision with reference to the status of inhabitants of $\mathbf{A}$ mandated territories, but inasmuch as these territories by Article 22 are provisionally recognized as independent nations, it seems clear that their inhabitants can not be assimilated to nationals of the mandatory.

The League's decisions with reference to the status of territory and inhabitants under mandate have been negative in character. League organs, as well as the South African court, have insisted that the mandatory is not sovereign, but have wisely avoided giving a final opinion as to the exact location of authority. It may be noticed, however, that in each of the controversies discussed, with the exception of that over the applicability of treason laws in Southwest Africa, the mandatory has recognized ${ }^{47}$ and the

"League of Nations Official Journal, 1923, 4: 568-572.

¿ Ibid., 4: 659.

46 Ibid., 4: 603 .

"See for instance, statement of Sir Edgar Walton, representative of South Africa before the subcommittee on national status: "The Union of South Africa had not yet taken any decision as to the nationality of these inhabitants, but it would be extremely grateful to the Council of the League of Nations if it would authorize the government to offer them British nationality." League of Nations Official Journal, s: 593, 598. 
League Council has insisted that decision upon these exercises of sovereign powers can only be made by the mandatory with consent of the League Council. These cases thus seem to support the present writer's suggestion that "there will be a close approach to truth in ascribing sovereignty of mandated territories to the mandatory acting with the consent of the Council of the League." 48 It appears that these two acting together can, in fact, determine the status of either inhabitants or territory of the mandated areas.

QUINCY WRIGHT.

\section{THE SETTLEMENT OF OUTSTANDING CLAIMS BETWEEN MEXICO AND THE UNITED STATES}

On September 8, 1923, a Convention for the Settlement of General Claims between Mexico and the United States was signed at Washington on behalf of the United States by Charles Evans Hughes, Secretary of State; Charles Beecher Warren, former Ambassador of the United States to Japan, and John Barton Payne, former Secretary of the Interior; and on behalf of Mexico by Manuel C. Téllez, Chargé d'Affaires ad interim of Mexico at Washington. The ratification of the treaty was advised by the Senate on January 23, 1924; ratified by the President of the United States on February 4, 1924; ratified by Mexico on February 16, 1924; ratifications exchanged at Washington on March 1, 1924, and proclaimed on March 3, 1924 . The convention, therefore, is a law both of the United States and of Mexico, the origin, the source and the measure of the general claims of the United States against the sorely tried Republic of Mexico.

The two countries had in mind a settlement of all outstanding claims, and as a part of the transaction a Special Claims Convention was negotiated for the settlement of claims of American citizens arising from revolutionary acts in Mexico from November 20, 1910, to May 31, 1920. This convention was signed in the City of Mexico on September 10, 1923, and, going through the various stages required by the laws of both, was proclaimed as law by the President of the United States on February 23, 1924. It is, therefore, the law of the two Republics, and, like the general convention, it is the source and measure of the special claims for which it was negotiated, which the Government of the United States has by its terms the right to present against the Government of Mexico, and in appropriate cases to receive compensation. In this case the situation was reversed. George F. Summerlin, Chargé d'Affaires ad interim of the United States, acted on behalf of his country, and Alberto J. Pani, the Mexican Secretary of State for Foreign Affairs, signed on behalf of his country. Reciprocity was observed, in that the General Claims Convention was signed in Washington, the official residence of the Secretary of State of the United States, and the Special

4 This Jouranal, 17: 698. 